\title{
Beach Resorts Operation as Potential Lake Water Pollutants: Sketches on Synergy among Stakeholders
}

\author{
Enrico Garcia
}

\begin{abstract}
The overarching goal of this paper is to contribute to the discourse on capitalism's collision with the environment. Particularly, this study examines the potential lake water pollution of the local beach resorts operations in Talisay, Batangas, Philippines. The increasing volume of wastes from beach resorts in the study sites is one of the major threats in the water quality of the Lake. Specific contributors of beach water pollutant include wastes from sewage system, boating, beach goers, fresh water debris, and plastic pollution. The average results of the water quality indicator tests elucidate that the Dissolved Oxygen $(3.59 \mathrm{mg} / \mathrm{L})$, Phosphate $(0.06 \mathrm{mg} / \mathrm{L})$, Nitrates $(2.53 \mathrm{mg} / \mathrm{L})$, and Chloride $(449 \mathrm{mg} / \mathrm{L})$ of the beach resorts sites of the study do not conform to the standards set by the Department of Environment and Natural Resources (DENR). T-test results show significant differences in Dissolved Oxygen and Phosphate test of two compared sites $(p<0.05)$ which clearly indicates water pollution. This paper sees the insistence for the Local Government Unit to strengthen the Local Sanitation Law for all beach resorts in the study sites. I provide preliminary sketches to protect the water quality of the Lake. I argue that the four main stakeholdersthe local government, the locals/entrepreneurs, beach resort owners and the tourists - need to create a synergy. This synergy, following Peter Evans, pertains to institutional partnerships and embeddedness of actors' relations, among others.
\end{abstract}

Keywords - Beach Resorts, Water Quality, Lake Water Pollution, Synergy

\section{INTRODUCTION}

The very attractive location and proximity to the country's capital gives Talisay, Batangas, Philippines and the rest of the towns surrounded by Taal Lake the potential to become one of the most important tourist destination of the country. The increasing demands of tourist give ways to more potential businessmen to operate beach resorts and to be consider as one of the income generating source of the town. Consequently, [1] considers the impact of tourism at two levels, the uncontrollable numbers of tourists that exceeds carrying capacity and the possible pollution brought by them. In the Philippines, disposal of wastewater is turning to be an enormous challenge. Untreated wastes are hazards to health and environment and may lead to epidemics, fish kills, and other related disasters. In line with this, the Philippine government has formulated policies and guidelines that will ensure proper management of the country's wastewater [2]. The Physico-chemical tests necessary to assess lake water quality are dissolved oxygen, $\mathrm{pH}$, chlorides, phosphates and nitrates Oxygen are important parameters of the lake water ecosystem which is essential to the metabolism of all aquatic organisms that possess aerobic respiration [3].

Determination of the water pollution from irregularities of environmental protection law was one of the major objectives of this study. The cooperation of all concern stakeholders in the protection of natural lake environment was necessary to the everlasting greater harmony between the lake environment and its residents. "State-society synergy" can be a promoter for development. Rules of cooperation and networks of municipal engagement among ordinary citizens can be promoted by public agencies and used for developmental ends. Figuring out how such public-private cooperation might show more widely should be a priority for those interested in development [4].

\section{A. Objectives of the Study}

The primary goal of this study is to contribute to the discourse on capitalism's collision with the environment, particularly it examines the potential lake water pollution of the local beach resorts operations in Talisay, Batangas, Philippines. Specifically, it aims to determine the lake water quality of Talisay beach resort sites; test the difference of water quality of two compared sites and sketch synergy among stakeholders in protecting Taal Lake waters.

\section{II.METHODOLOGY}

\section{A. Study Site}

Located at $\left(14^{\circ} 00, \mathrm{~N}, 121^{\circ} 19\right.$, E), Taal Lake known as Lake Bombon, is the deepest and the third largest lake in the Philippine Archipelago. It is classified as an oligotrophic lake with a maximum depth of 180 meters and drains through the Pansipit River into Balayan Bay to the southwest [5]. The Lake was declared as protected area in 1996 with thirty-seven (37) tributaries drain into the Lake and its only outlet is the Pansipit River (Asian Development Bank, 2003) as cited by [6] 


\section{B. Data Analysis}

The collected water samples were immediately tested to find the results of the physico-chemical analysis. The approved methods of analysis set by the Department of Environment and Natural Resources ("PRIME - M4 Page 1 of 11," 1990) were used. Weighted mean of each physico-chemical analysis were compared against the standard set by the Department of Environment and Natural Resources- Environment (DENREMB, Administrative Order no. 34, 1990) [7]. T-test for equality of means were used to test the difference of water quality of two compared sites and link the results to Peter Evans "state-society" synergy methods and evidence pertaining to institutional partnerships and embeddedness of actors' relations, among others.

\section{RESULTS AND DISCUSSION}

\section{A. Lake Water Quality Test Results}

The lake water quality tests of two compared sites were measured by getting the averages of three trials. Site A, representing the two beach resorts of the east side of Talisay namely, barangay Aya and Tumaway and Site B characterizes the concentrated beach resorts of the west side of Talisay (Baranggays Buco to Sampalok.

TABLE I

WEIGHTED MEAN OF WATER QUALITY TESTS OF TWO COMPARED SITES

\begin{tabular}{|c|c|c|c|c|c|}
\hline & $\begin{array}{c}\text { Site } \\
\text { A }\end{array}$ & $\begin{array}{c}\text { Site } \\
\text { B }\end{array}$ & Mean & $\begin{array}{c}\text { Standard } \\
\text { Set by } \\
\text { DENR- } \\
\text { EMB }\end{array}$ & $\begin{array}{c}\text { Interpretatio } \\
\mathrm{n}\end{array}$ \\
\hline $\mathrm{pH}$ & 8.3 & 8.6 & 8.5 & $6.7-8.5$ & $\begin{array}{l}\text { Within the } \\
\text { standarad }\end{array}$ \\
\hline $\begin{array}{c}\text { Phosphate } \\
\text { s }\end{array}$ & $\begin{array}{c}.03 \\
\mathrm{mg} / \mathrm{L}\end{array}$ & $\begin{array}{c}.08 \\
\mathrm{mg} / \mathrm{L}\end{array}$ & $\begin{array}{c}.06 \\
\mathrm{mg} / \mathrm{L}\end{array}$ & $\begin{array}{c}.01-.03 \\
\mathrm{mg} / \mathrm{L}\end{array}$ & $\begin{array}{l}\text { Exceed the } \\
\text { standard }\end{array}$ \\
\hline Nitrates & $\begin{array}{c}2.42 \\
\mathrm{mg} / \mathrm{L}\end{array}$ & $\begin{array}{c}2.63 \\
\mathrm{mg} / \mathrm{L}\end{array}$ & $\begin{array}{c}2.53 \\
\mathrm{mg} / \mathrm{L}\end{array}$ & $\begin{array}{c}\text { below } 1 \\
\text { mg/L }\end{array}$ & $\begin{array}{l}\text { Excedd the } \\
\text { standard }\end{array}$ \\
\hline Chloride & $\begin{array}{c}445 \\
\mathrm{mg} / \mathrm{L}\end{array}$ & $\begin{array}{c}452 \\
\mathrm{mg} / \mathrm{L}\end{array}$ & $\begin{array}{r}449 \\
\mathrm{mg} / \mathrm{L}\end{array}$ & $\begin{array}{c}\text { Below } 25 \\
\mathrm{mg} / \mathrm{L}\end{array}$ & $\begin{array}{l}\text { Exceed the } \\
\text { standard }\end{array}$ \\
\hline $\begin{array}{l}\text { Dissolved } \\
\text { Oxygen }\end{array}$ & $\begin{array}{c}3.74 \\
\mathrm{mg} / \mathrm{L}\end{array}$ & $\begin{array}{c}3.44 \\
\mathrm{mg} / \mathrm{L}\end{array}$ & $\begin{array}{c}3.59 \\
\mathrm{mg} / \mathrm{L}\end{array}$ & $\begin{array}{l}* 6 \mathrm{mg} / \mathrm{L} \\
\text { minimun }\end{array}$ & $\begin{array}{l}\text { Below the } \\
\text { standard }\end{array}$ \\
\hline
\end{tabular}

Despite of the few presence of beach resorts in site A, still the computed value of nitrates, chlorides and dissolved oxygen (DO) do not conform on the standard set by Department of Environment and Natural Resources. Results may be based on the factors such as poor drainage system and sewage disposal of the beach resorts and neighboring residences, presence of numerous farm lots near the lake and uncontrollable drainage system patterns from upper land and canals. In site B, results shows that all water quality tests do not conform to the standards set by the Department of Environment and Natural Resources. Beach resorts observation such as poor drainage and sewage system, pollution from boating, beach goers wastes disposal, fresh water debris, and plastic pollution maybe the contributor to the results.

\section{B. Test of Difference}

TABLE II

T-TEST FOR EQUALITY OF MEANS

\begin{tabular}{lcc}
\hline $\begin{array}{l}\text { Physico- } \\
\text { Chemical } \\
\text { Analysis }\end{array}$ & $\mathrm{t}$ & Sig (2-tailed) \\
\hline $\mathrm{pH}$ & -1.66 & .173 \\
Phosphates & -7.60 & $.002^{*}$ \\
Nitrates & -1.42 & .228 \\
Chlorates & -2.77 & 0.52 \\
$\begin{array}{l}\text { Dissolved } \\
\text { Oxygen }\end{array}$ & 3.12 & $0.35^{*}$ \\
\hline
\end{tabular}

Table 2 shows the $t$ - test result of site 1 and site 2 for equality of means. The result shows that there is a significant difference in phosphates (.002) and dissolved oxygen (.035) of the two sites at Taal Lake. The dissolved oxygen level of a receiving water maybe depleted by some inorganic waste discharges such as fertilizers and sewage disposal while phosphates occurs widely in nature in plants, in microorganisms, in animal wastes and so on. It is widely used as an agricultural fertilizer and as a major constituent of detergents, particularly those for domestic use. Run-off and sewage discharges are thus important contributors of phosphorus to surface waters [8] The consequence is that the actual concentrations of DO in a lake will be lowest in summertime when it is usually the case that the risk of damage to a water supply source or of environmental pollution is greatest, especially in areas developed as tourist centers or where such farming operations as silage-making are carried on [9]

The significance of phosphate is principally in regard to the phenomenon of eutrophication (over-enrichment) of lakes. Phosphates gaining access to such water bodies, along with nitrogen as nitrate, promotes the growth of algae and other plants leading to blooms, littoral slimes, diurnal dissolved oxygen variations of great magnitude and related problems [10]. Subsequently dissolved oxygen and phosphates has no direct health implications, but an important indicator of overall water quality, Taal Lake, particularly beach resorts in Talisay can be still be used for primary contact recreation such as bathing, swimming, and skin diving.

\section{Synergy among Stakeholders in Protecting Taal Lake Waters}

The main stakeholders concerned in the protection of Taal Lake waters are: Local Government Unit (LGU), locals/entrepreneurs, beach owners/operators, and tourists. The Local Government Unit (LGU) primarily has the obligation to strict the implementation of the policy regarding sanitation code. The goal of sustainable development in the area of lake waters will have a great effect in the improvement of tourism industry that's benefits all the stakeholders. Beach owners, on 
the other hand must comply in the national sanitation code for the continuous effort of maintaining the required water quality of the beach waters. Lake water pollution pose a great threats in the water quality of the lake and will be greatly affect the local economy resulting from decreasing number of tourists as well as quality of catched fishes affected by water pollution. Locals/entrepreneurs and tourists also has a great contributions of lake water pollution and it must be controlled. The concerned stakeholders can be organized by both LGU and beach resorts owners as they have a great influence in imparting sustainable development practices.

In relation, "State-society synergy," that active government and mobilized communities can enhance each other's developmental effort and it can be also a promoter for progress. Rules of cooperation and networks of civic engagement among ordinary citizens can be promoted by public agencies and used for developmental ends. Figuring out how such public-private cooperation might flourish more widely should be a priority for those interested in development [11]

\section{CONCLUSION AND RECOMMENDATION}

All water quality tests conducted in Site B which represents the west side and the concentrated area of beach resorts do not conform in the standards set by DENR. T-test for equality of means shows significant difference in phosphates (.002) and dissolved oxygen (.035) level which considers as sign of water pollution. I argue that the four main stakeholders - the local government, the locals/entrepreneurs, beach resort owners and the tourists - need to create a synergy. This synergy, following Peter Evans, pertains to institutional partnerships and embeddedness of actors' relations, among others.

The study will recommend the strict implementation of the Local Government Unit of Talisay, Batangas in the compliance of local sanitation code for beach resorts. Responsible agencies must have a frequent monitoring of water quality and immediate action to mitigate the later problems. A follow-up study on synergetic relationship among stakeholders in protecting Taal lake waters will also be recommended.

\section{REFERENCES}

[1] J. Davenport and J. L. Davenport, "The impact of tourism and personal leisure transport on coastal environments : A review," vol. 67, pp. 280292, 2006.

https://doi.org/10.1016/j.ecss.2005.11.026

[2] B. Environment and H. S. Series, Philippine Regulations on Sanitation and Wastewater Systems, vol. 2. .

[3] M. Theresa, "Assessment of local government' s implementation of open access policy in Taal Lake, Philippines: Effects on lake conservation and management .," 2015.

[4] Author: State-Society Synergy: Government and Social Capital in Development Edited by Peter Evans. 1997.

[5] R. D. S. Papa, R. C. Pagulayan, and A. E. J. Pagulayan, "Zooplanktivory in the Endemic Freshwater Sardine," vol. 47, no. 5, pp. 535-543, 2009.

[6] T. Lake and F. B. Martinez, "MONITORING AND EVALUATION OF THE WATER QUALITY OF," vol. 1, no. 1, pp. 229-236, 2011.

[7] “PRIME - M4 Page 1 of 11," no. 34, pp. 1-11, 1990.

[8] V. T. Cabading, "Water Quality Management in the Philippines Vilma T. Cabading," vol. 2004.
[9] B. Badar, S. A. Romshoo, and M. A. Khan, "Integrating biophysical and socioeconomic information for prioritizing watersheds in a Kashmir Himalayan lake : a remote sensing and GIS approach," 2013.

[10] B. Brazil, A. P. F. S. Costódio, K. N. Kuroshima, M. A. B. Barreiros, P. F. S. Cost, and A. Barreirosf, "Correlation Between Total Bacteria and Inorganic Nutrients in Water of Camboriú River Stable URL: http://www.jstor.org/stable/25742979 Linked references are available on JSTOR for this article : River and Beach ( Brazil ) Correlation Between Total Bacter," no. 39, 2016.

[11] P. Evans, "GOVERNMENT ACTION , SOCIAL CAPITAL AND DEVELOPMENT: REVIEWING THE EVIDENCE ON SYNERGY," pp. $178-20$ 